\title{
Reflections
}

\section{Youth-led climate strikes: fresh opportunities and enduring challenges for youth research - commentary to Bowman}

\author{
BRONWYN ELISABETH WOOD
}

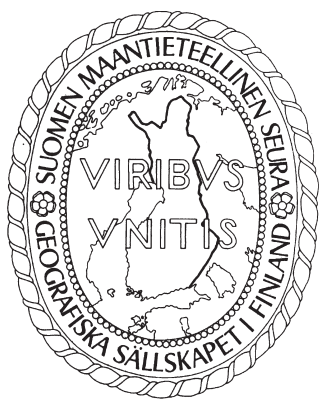

Wood, B. E. (2020) Youth-led climate strikes: fresh opportunities and enduring challenges for youth research - commentary to Bowman. Fennia 198(1-2) Xx-xx. https://doi.org/10.11143/fennia.91089

In this commentary I respond to Benjamin Bowman's Fennia paper by extending upon his central thesis that argues that the prevailing methodological tools and framings used to research youth political participation perpetuate unhelpful and inadequate dichotomies about youth. Advancing upon this, I suggest that the youth climate strikes in 2019 highlight three prevalent discourses in youth research relating to climate change: (i) the tendency to view youth as isolated individuals, neglecting the role of adults and communities; (ii) the tendency to focus on individual behavioural change rather than recognise the need for systemic and societal responses to climate change, and (iii) the tendency to overlook structural characteristics of youth such as race, gender and social class. The resulting discourses of youth autonomy, individualism and homogeneity lead to a distorted picture of young activists and perpetuate harmful narratives which lead to stigma, despair and cynicism. The paper concludes by advocating for greater care in the research methodologies and critical frameworks we use to report on youth at public events, such as climate strikes, in order to allow for the complexity of the young political agent, the ambiguity of some of their actions and for opportunities that enable young people themselves to articulate their own participation.

Keywords: climate strikes, youth, methodology, climate change, individualism

Bronwyn Elisabeth Wood, Victoria University of Wellington, Te Herenga Waka, Faculty of Education, P.O. Box 600, Wellington 6140, New Zealand. E-mail: Bronwyn.Wood@vuw.ac.nz.ORCID: https://orcid.org/0000-0003-3560-2194

\section{Introduction}

The scale of youth-led and youth participation in the protests for climate action in 2019 (variously known as StudentStrike4Climate (SS4C), FridaysForFuture or Youth Strike4Climate) warranted considerable attention with the final global strike amassing more than six million people in countries as diverse as Ghana, Brazil, Samoa and the Philippines (Taylor et al. 2019). In my country of New Zealand, I joined more than 3.5\% of the population taking to the streets on September 27 to demand urgent action on the escalating ecological crisis (Taylor et al. 2019). Yet what does this wide-scale youth activism mean for climate action and for researchers? And what insights can we glean from a Creative Commons Attribution 4.0 International License. 
the 2019 climate strikes about how young people are represented, researched and discussed? In this commentary I take a lead from Bowman's (2019) paper recently published in Fennia to examine the 2019 climate strikes and consider some of the opportunities and challenges they present to researchers of children and young people.

As researchers, we have been left somewhat on the backfoot in capturing the youth-led climate strike social movement. Bowman's (2019) paper makes an important early contribution to this emerging field of research. His paper responds to Wahlstrom and colleagues' (2019) report on the March 15, 2019 climate strikes in 13 countries in Europe which is, to-date, the most extensive survey of protest participants in Europe. Whilst recognising the significant contribution of this report, Bowman critiques the adult-led and binary framing of the political action of young people used in the report arguing that it overlooks the complexity of youth politics. For example, he argues that the focus on emotions of 'worry' and 'anger' overlook the joy and sense of fun that characterised many of the protests. In addition, the construction of binaries such as 'instrumental' or 'expressive' motivations for protesting perpetuate a false dichotomy that centres on older and more traditional notions of politics. Bowman (2019) proposes that such narratives overlook the significant work by researchers in youth politics which have pointed to the importance of understanding Do-lt-Ourselves forms of political participation (Pickard 2019) and the lived, 'everyday politics' of young people how these inform our understanding of young citizens (O'Toole et al. 2003; Bang 2004; Harris et al. 2010; Wood 2012, 2014; Kallio \& Häkli 2013). A key argument Bowman makes is that the prevailing methodological tools and framings used to research youth political participation perpetuate unhelpful and inadequate dichotomies (active/non-active; formal/informal) about youth. In response, he suggests that we need methodological approaches and theoretical frames that are better equipped to deal with the complexity of the young political agent, the ambiguity of some of their actions and opportunities that enable young people themselves to articulate their own participation.

\section{Three research challenges}

Research into the climate strikes does present some unique challenges to researchers - not least because of the scale, the spontaneity and the short-term nature of the protest action itself which allows little time for preparation and follow up - but also because of the immediate attention it demanded due to the intense media and adult scrutiny on young people. In my commentary I take up Bowman's challenge and use the climate strikes as a starting point to consider three ongoing challenges for research in this emerging field. These challenges sit at the intersection of our responses to issues of environmental degradation and climate change and how we research youth in general, as well as their involvement in the strikes. From my perspective, these are closely related and as I will argue, deeper understandings of both are required.

\section{Youth - isolated, alone and angry: where are the adults?}

One of the most significant elements of the 2019 climate protests is that they were youth-led. This generated considerable interest in how young people, who had no experience of political organising, managed to co-ordinate national and global level protests of such scale (Thomas et al. 2019). The novelty of this youth-led focus merited much attention and indeed more research is needed into how this movement was mobilised by young people within and across nations. This focus on youth as political agents is part of a wider growing interest in the past two decades on children and young people as young social agents and political actors (Holloway et al. 2010). Yet, this attention has at times come at the detriment of a wider awareness of young people's broader connections in communities and their relationships with others. The focus on youth alone has led to a tendency to celebrate agency and view youth as isolated, bounded, individual subjects. I agree with others who suggest that at times this has had "too sharp and too exclusive a focus on the standpoints of young people" (Fielding 2007, 304). This attention has at times overstated the autonomy of youth participation and understated the powerful roles that adults play - especially in the context of families and regulated spaces such as schools (Wyness 2013; Bartos 2015; Wood et al. 2018). 
This focus on youth alone was notable in some of the media reporting of youth climate protests. Such reporting often used a generational analysis to conclude that the strikes represented an angry young generation - isolated and alone (The Guardian 2019) and often in opposition to adults who had created the environmental mess. This was a feature of much media where students were pitted against adults in an oppositional response, such as Jemima Grimmer, 13, in Sydney who stated: "Adults are, like, 'Respect your elders.' And we're, like, 'Respect our futures. You know, it's a two-way street, respect, and I'm angry that I have to be here." (Sengupta 2019).

Such reporting overlooked the intergenerational responses which did exist in all of the protests (Carrington 2019) and is essential if issues of climate justice are to be addressed. Youth are not isolated individuals and nor does their knowledge, skills and actions stem from a world removed from adults. Instead, it is more useful to see the strikes are part of a wider inter-generational globally-connected form of political organising (Thomas et al. 2019) that has had a much longer presence than the events of 2019.

This is challenging for researchers who struggle to adequately capture the community and intergenerational elements of young people's lives as this requires a more wholistic vision and significantly more time in the field than a one-off interview with a protesting individual. However, this is more important than it might appear, because the complexity of climate change and its solutions require many people, diverse communities and multiple-pronged approaches. In the same way, we as researchers require a bigger vision to explore the inter-related, networked and relational elements of young people's lives more accurately (Mannion 2007; Bartos 2012, 2013; Holloway et al. 2019; Wood \& Kallio 2019). In addition, we need to remember the significance that everyday interactions and familiar spatial and social practices hold in creating environmental awareness and a desire to care, protect and nurture places of belonging that may be under threat, and not merely focus on one-off high profile events (Bartos \& Wood 2017).

\section{Focus on Individual Behavioural Change}

Closely linked to the first challenge is a prevailing tendency in discourses of climate change to focus on the individual and their associated actions to address environmental damage and climate change. Known as Individual Behavioural Change (IBC) (or sometimes ABC (Attitude-BehaviourChoice), the responsibility for responding to climate change is thought to lie with individuals whose behavioural change will make the difference (Shove 2010). This common approach focuses on an individual's own actions to reduce environmental and climate impacts - such as recycling, using reusable bags, reducing carbon footprint, eating less meat and so on. While this has some merits, it has been found to be closely associated with growing levels of 'eco-anxiety', guilt and despair amongst children, young people and climate activists (Christensen 2019; Lawton 2019; Nairn 2019; Thomas et al. 2019). These prevailing and individualising anxieties make their way into how we research, with a good example being the Wahlström and colleagues (2019) report which overlooked the joyful and hopeful aspects of the climate strikes, focusing instead on anxiety, fear and hopelessness due to the narrow framing of the methodology (Bowman 2019).

In the same way, discourses about individual behavioural change heighten feelings of guilt and normalise eco-anxiety as a constant state of inadequacy by placing far too much weight on the individual's own responses. IBC is highly problematic as a solution as it ignores the structural and systemic political and economic systems responsible for thousands of years of environmental degradation and exploitation and suggests that an individual can address this through their carbon-reducing behavioural change (Shove 2010; Rice et al. 2015; Christensen 2019). As Maniates (2001, 33) explains:

When responsibility for environmental problems is individualized, there is little room to ponder institutions, the nature and exercise of political power, or ways of collectively changing the distribution of power and influence in society - to, in other words, "think institutionally."

Christensen's (2019) study of climate activists in Auckland, New Zealand confirms this pattern. She showed that an IBC approach detracted young people from deeper engagement with the difficult 
work of thinking about the underlying causes of climate change, including the emotional work involved in imagining different and new alternatives to current socio-economic and socio-political realities. Another New Zealand-based study of climate activists also reported high levels of despair, burnout and eco-anxiety, but found hope through recognising the strength that collective, rather than individual, responses that climate change could bring (Nairn 2019). These studies suggest that researchers need to pay far more attention to the imaginations of young activists themselves and allow possibilities to see collective hope and solidarity, not only despair and the need to embed this in theoretical and methodological frameworks. This brings us to a third challenge for researchers engaged in climate change politics - the need to consider the collective rather than individual identities of young protesters.

\section{Focus on structural and identity politics}

Bowman (2019) highlights the importance of knowing more about the classed, raced and gendered characteristics of climate strike participants. While there was no data on race from the protests in Europe (Wahlström et al. 2019), the report identified a higher number of female protesters than male and some indication that they were from middle class or well-educated backgrounds with $73 \%$ with a parent with at least one university degree (Wahlström et al. 2019). This pattern confirms earlier studies of young people interested in environmental issues, which report similar high female and middleclass representation (Chawla 2007; Kraus et al. 2012; Eom et al. 2018). For example, a survey of members of Generation Zero, a youth-led environmental activist group in New Zealand, found a largely homogenous membership made up of middle-class, European-origin young people with Green Party political affiliations (Dodson \& Papoutsaki 2017). The authors of this study conclude that a wider adoption of pro-environmental attitudes, beliefs and engagement will remain rather limited unless it can expand from this rather narrow and homogenous support base. In addition, while studies suggest climate change holds more interest to higher socio-economic groups, questions are raised about whether this apparent lack of interest may reflect deeper structural barriers - such as limited time and resources - for lower SES people who therefore do not have the luxury (or sense of control over external forces) to act on beliefs (Kraus et al. 2012).

Whilst information about structural forces, social groups, gender, race and class are invaluable, in recent times, youth studies have frequently limited a focus on these variables (France et al. 2018). In fact, some have gone so far as to say that 'class is dead' (Pakulski \& Waters 1996) - a 'zombie category' (Beck \& Beck-Gernsheim 2002) that holds little relevance to youth today, with some advocating for a much greater focus on social generation (Woodman 2009). These debates highlight the importance of gathering thorough and careful data about climate strike participants in ways that provide deeper insights into the communities that young people represent and the extent to which they are shaped by broad structural forces which characterise gender, class and race. This may reveal further the limitations of narrow individualist characteristics in explaining why and how young people are involved in environmental climate strikes.

\section{Conclusion}

In sum, some incredible opportunities are available for researchers to engage with the climate strikes and the role young citizens played in these. However, building on Bowman's (2019) argument, I have also identified some of the prevailing discourses of youth autonomy, individualism and weak notions of community, social groups and structural forces that were present in the representation of young participants in the climate strikes. Such approaches can lead to a distorted picture of young activists and perpetuate harmful narratives which lead to despair and cynicism. These narrow frameworks also give rise to limited notions of youth themselves and the ways they are understood as young citizens. Paying attention to the research methodologies we choose, the critical frameworks we use and the unintended consequences of how we report (such as those heightening feelings of helplessness and despair (see Thomas et al. 2019 for more on this argument)), is one contribution we can make to 
provide more nuanced and accurate representation of youth and climate change justice. As Christensen $(2019,85)$ states:

Future research in this area should focus on what methods of engagement are useful and productive for channelling young people's fears and anxieties into resilience and motivation about creating new ways of thinking, operating, organizing and feeling in this time of climate transformation.

\section{References}

Bang, H. (2004) Everyday makers and expert citizens: building political not social capital. Australia National University, School of Social Science, Australia. https://digitalcollections.anu.edu.au/ bitstream/1885/42117/2/Henrik.pdf

Bartos, A. E. (2012) Children caring for their worlds: the politics of care and childhood. Political Geography 31(3) 157-166. https://doi.org/10.1016/j.polgeo.2011.12.003

Bartos, A. E. (2013) Friendship and environmental politics in childhood. Space and Polity 17(1) 17-32. https://doi.org/10.1080/13562576.2013.780711

Bartos, A. E. (2015) Children and young people's political participation: a critical analysis. In Kallio, K. P., Mills, S. \& Skelton, T. (eds.) Politics, Citizenship and Rights, 1-15. Springer Singapore, Singapore. https://doi.org/10.1007/978-981-4585-94-1_1-1

Bartos, A. E. \& Wood, B. E. (2017) Ecological wellbeing, childhood, and climate change In Ergler, C., Kearns, R. \& Witten, K. (eds.) Children's Health and Wellbeing in Urban Environments, 234-246. Routledge, Oxon and New York. https://doi.org/10.4324/9781315571560-17

Beck, U. \& Beck-Gernsheim, E. (2002) Individualization. Sage, London.

Bowman, B. (2019) Imagining future worlds alongside young climate activists: a new framework for research. Fennia 197(2) 295-305. https://doi.org/10.11143/fennia.85151

Carrington, D. (2019) Parents around the world mobilise behind youth climate strikes. The Guardian 3.4.2019< <https://www.theguardian.com/environment/2019/apr/03/parents-around-the-worldmobilise-behind-youth-climate-strikes $>$. 5.3.2020.

Chawla, L. (2007) Childhood experiences associated with care for the natural world: a theoretical framework for empirical results. Children, Youth and Environments 17(4) 144-170.

Christensen, E. (2019) Fearful of the future and paranoid about the present: the emotional geographies of young climate activists in Auckland, New Zealand. Master thesis. University of Auckland, Auckland.

Dodson, G. \& Papoutsaki, E. (2017) Youth-led activism and political engagement in New Zealand: a survey of Generation Zero. Communication Research and Practice 3(2) 194-211. https://doi.org/10.1080/22041451.2016.1228994

Eom, K., Kim, H. S. \& Sherman, D. K. (2018) Social class, control, and action: socioeconomic status differences in antecedents of support for pro-environmental action. Journal of Experimental Social Psychology 77 60-75. https://doi.org/10.1016/j.jesp.2018.03.009

Fielding, M. (2007) 'Beyond voice': new roles, relations and contexts in researching with young people. Discourse: Studies in the cultural politics of education 28(3) 301-310. https://doi.org/10.1080/01596300701458780

France, A., Roberts, S. \& Wood, B. (2018) Youth, social class and privilege in the antipodes: towards a new research agenda for youth sociology. Journal of Sociology 54(3) 362-380. https://doi.org/10.1177/1440783318786580

Harris, A., Wyn, J. \& Younes, S. (2010) Beyond apathetic or activist youth: 'ordinary' young people and contemporary forms of participation. Young 18(1) 9-32. https://doi.org/10.1177/110330880901800103

Holloway, S. L., Holt, L. \& Mills, S. (2019) Questions of agency: capacity, subjectivity, spatiality and temporality. Progress in Human Geography 43(3) 458-477. https://doi.org/10.1177/0309132518757654

Kallio, K. P. \& Häkli, J. (2013) Children and young people's politics in everyday life. Space and Polity 17(1) 1-16. https://doi.org/10.1080/13562576.2013.780710

Kraus, M. W., Piff, P. K., Mendoza-Denton, R., Rheinschmidt, M. L. \& Keltner, D. (2012) Social class, solipsism, and contextualism: how the rich are different from the poor. Psychological Review 119(3) 546-572. https://doi.org/10.1037/a0028756

Lawton, G. (2019) I have eco-anxiety but that's normal. New Scientist 244(3251) 22-22. https://doi.org/10.1016/S0262-4079(19)31914-1

Maniates, M. (2001) Individualization: plant a tree, ride a bike, save the world? Global Environmental Politics 1(3) 31-52. https://doi.org/10.1162/152638001316881395 
Mannion, G. (2007) Going spatial, going relational: why 'listening to children' and children's participation needs reframing. Discourse: Studies in the cultural politics of education 28(3) 405-420. https://doi.org/10.1080/01596300701458970

Nairn, K. (2019) Learning from young people engaged in climate activism: the potential of collectivizing despair and hope. Young 27(5) 435-450. https://doi.org/10.1177/1103308818817603

O'Toole, T., Lister, M., Marsh, D., Jones, S. \& McDonagh, A. (2003) Turning out or left out?: participation and non-participation among young people. Contemporary Politics 9(1) 45-61. https://doi.org/10.1080/1356977032000072477

Pakulski, J. \& Waters, M. (1996) The Death of Class. Sage, London.

Pickard, S. (2019) Politics, Protest and Young People: Political Participation and Dissent in 21st Century Britain. Palgrave MacMillan, London. https://doi.org/10.1057/978-1-137-57788-7

Rice, J. L., Burke, B. J. \& Heynen, N. (2015) Knowing climate change, embodying climate praxis: experiential knowledge in Southern Appalachia. Annals of the Association of American Geographers 105(2) 253-262. https://doi.org/10.1080/00045608.2014.985628

Sengupta, S. (2019) Protesting climate change, young people take to the streets in a global strike. The New York Times 20.9.2019 <https://www.nytimes.com/2019/09/20/climate/global-climate-strike.htm/>. 6.3.2020.

Shove, E. (2010) Beyond the ABC: climate change policy and theories of social change. Environment and Planning A: Economy and Space 42(6) 1273-1285. https://doi.org/10.1068/a42282

Taylor, M., Watts, J. \& Bartlett, J. (2019) Climate crisis: 6 million people join in latest wave of global protests. The Guardian 27.9.2019 <https://Www.theguardian.com/environment/2019/sep/27/climatecrisis-6-million-people-join-latest-wave-of-worldwide-protests> . 6.3.2020.

The Guardian (2019) Climate change and a betrayed generation 1.3.2019 <https://www.theguardian. com/environment/2019/mar/01/youth-climate-change-strikers-open-letter-to-world-leaders>. 3.2.2019.

Thomas, A., Cretney, R. \& Hayward, B. (2019) Student Strike 4 Climate: justice, emergency and citizenship. New Zealand Geographer 75(2) 96-100. https://doi.org/10.1111/nzg.12229

Wahlström, M., Kocyba, P., De Vydt, M. \& De Moor, J. (2019) Protest for a future: composition, mobilization and motives of the participants in Fridays For Future climate protests on 15 March, 2019 in 13 European cities. <http://eprints.keele.ac.uk/6571/7/20190709_Protest\%20for\%20a\%20 future GCS\%20Descriptive\%20Report.pdf>

Wood, B. E. (2012) Crafted within liminal places: young people's everyday politics. Political Geography 31(6) 337-346. https://doi.org/10.1016/j.polgeo.2012.05.003

Wood, B. E. (2014) Researching the everyday: young people's experiences and expressions of citizenship. International Journal of Qualitative Studies in Education 27(2) 214-232. https://doi.org/10.1080/09518398.2012.737047

Wood, B. E. \& Kallio, K. P. (2019) Green citizenship: towards spatial and lived perspectives. In Divoudi, S., Cowell, R., White, I. \& Blanco, H. (eds.) The Routledge Companion to Environmental Planning. Routledge, London and New York. https://doi.org/10.4324/9781315179780-18

Wood, B. E., Taylor, R. \& Atkins, R. (2018) Student voice, citizenship and regulated Spaces. In Bourke, R. \& Loveridge, J. (eds.) Radical Collegiality Through Student Voice: Educational Experience, Policy and Practice, 179-196. Springer Singapore, Singapore. https://doi.org/10.1007/978-981-13-1858-0_11

Woodman, D. (2009) The mysterious case of the pervasive choice biography: Ulrich Beck, structure/ agency, and the middling state of theory in the sociology of youth. Journal of Youth Studies 12(3) 243-256. https://doi.org/10.1080/13676260902807227

Wyness, M. (2013) Children's participation and intergenerational dialogue: bringing adults back into the analysis. Childhood 20(4) 429-442. https://doi.org/10.1177/0907568212459775 